\title{
Study of Genetic Divergence in Pea (Pisum sativum L.) based on Agro-Morphic Traits
}

\author{
Archi Gupta ${ }^{1}$, M.K. Singh ${ }^{1}$, Mukesh Kumar ${ }^{1}$, S.K. Singh ${ }^{2}$, \\ Hariom Katiyar ${ }^{3}$ and Vipin Kumar ${ }^{*}$ \\ ${ }^{1}$ Department of Horticulture, ${ }^{2}$ Department of Genetics and Plant Breeding, ${ }^{3}$ Directorate of \\ Extension, SVPUAT, Meerut-250110, UP, India \\ *Corresponding author
}

\section{A B S T R A C T}

\begin{tabular}{|l|}
\hline Ke y w o r d s \\
Genetic divergence, \\
Agro-morphic traits, \\
Horticulture
\end{tabular}

The investigation was carried out with 20 genotypes of pea (Pisum sativum L.) at Horticulture Research Centre (HRC) of SVPUAT, Meerut, UP during 2016-17 to study the genetic diversity among the genotypes. The experiment was laid down in randomized block design (RBD) with 03 replications. The experiment having 10 observations on the basis of 5 randomly selected plants from each replication. $\mathrm{D}^{2}$ analysis grouped into four clusters showing the existence of considerable amount of variation among the genotypes. Maximum pod yield $73.20 \mathrm{q} / \mathrm{ha}$ was found in PB-89 genotype. Cluster pattern revealed that, cluster III had largest number of genotypes (10) followed by cluster II ( 5 genotypes), cluster IV (3 genotypes) and cluster I had only (2 genotypes). Highest intra cluster distance were found cluster II $\left(\mathrm{D}^{2}=1.983\right)$ whereas, highest inter cluster distance was observed between cluster III and I $\left(\mathrm{D}^{2}=6.627\right)$. The cluster means revealed the best cluster for various growth and flowering traits, depending upon the aim of breeding, hence the potential line can be selected from different clusters as parents.

\section{Introduction}

Vegetables are truly known as functional food and contain those ingredients that add bodily functional food in addition being nutritious and are also known as protective food. They are rich source of vitamins, carbohydrates, proteins etc. Vegetables are commonly used as culinary purposes.

Pea (Pisum sativum L.) is a very unique nutritious vegetable and used in Indian kitchen. Pea has unique distinction on account of their utility as pulse as well as vegetable. Green pea is generally used as vegetable.
It is a highly nutritious vegetable and contains digestible protein $7.2 \mathrm{~g}$, carbohydrates $15.8 \mathrm{~g}$, fat $0.1 \mathrm{~g}$, vitamins like vitamin C $9 \mathrm{mg}$, vitamin A 139 IU and minerals like calcium $20.0 \mathrm{mg}$ phosphorus $139 \mathrm{mg}$, iron $1.5 \mathrm{mg}$ (Choudhary, 1990). Besides these, pea adds additional plant nutrient like nitrogen in soil by nitrogen fixation by useful bacteria i.e., rhizobium. Pea belongs to the family Leguminosae (Fabaceae) and having chromosome number $2 \mathrm{n}=14$. It is an annual herbaceous plant and commonly known as leguminous vegetable crop. Pea is an important plant in human and animal nutrition 
because of it has high protein content 23$33 \%$. Green peas are eaten cooked as a vegetable and are marketed fresh, canned or frozen. Peas are rich in health benefiting phyto-nutrients, minerals, vitamins and antioxidants.

The breeder need to isolate the suitable genotypes on the basis of genetic divergence for the hybridization purpose, Mahalanodis $\mathrm{D}^{2}$ statistics techniques based on multivariate analysis of quantitative among the group. It also pin-points suitable genotype for their utilization in hybridization programmes.

In order to produce transgressive segregants and genetically different parents must to be selected for recombination breeding in selfpollinated crops. The characterization of genetic diversity in crop species has long been based on morphological attributes, however, morphological variation is often found to be of limited use because the expression of morphological attributes may be affected by environmental conditions, thereby constraining the analysis of genetic variation (Nisar et al., 2008). On the basis of morphological data, genetic diversity assessments needs a high precision of field experiments through recommended design and analysis so that the germplasm may be exploited to develop better genotypes for the upcoming scenario (Sajjad et al., 2011). Knowledge of genetic diversity is a useful tool in gene bank management and in planning experiments, as it facilitates efficient sampling and utilization of germplasm by identifying and/or eliminating duplicates in the gene stock and helps in the establishment of core collections (Ghafoor et al., 2005).

\section{Materials and Methods}

A total of 20 genotypes of pea collected for divergence study (Table 3). The present investigations were carried out in 2016-17 at
Research Farm of HRC, SVPUAT, Meerut in RBD method with three replications. Each plot comprised one row of $1.8 \mathrm{~m}$ length spaced $45 \mathrm{~cm}$ with plant to plant and row to row is $10 \mathrm{~cm}$. All the recommended cultural practices were followed under irrigated conditions as and when needed. The observations were recorded on five random competitive plants per replication for each genotype of ten important characters i.e. days to $50 \%$ flowering, plant height $(\mathrm{cm})$, number of first fruiting node, length of first fruiting node $(\mathrm{cm})$, number of pods per plant, length of pod $(\mathrm{cm})$, width of pod $(\mathrm{cm})$, number of seeds per pod, pod yield per plant (g), pod yield (q/ha). The Mahalanobis $\mathrm{D}^{2}$ (1936) statical method was used to quantify genetic diversity among the genotypes. The $\mathrm{D}^{2}$ values were used to classify the entire germplasm into distinct clusters, which was done following to Tocher's method [Rao (1952)].

\section{Results and Discussion}

The analysis of variance for 20 genotypes of pea revealed significant difference for all the 10 characters, which indicated the presence of wide spectrum of variability among the genotypes. The minimum flowering duration (32.67) was observed with the cultivar E-6 and plant height was observed with the genotypes Sel- 3. Genotype Sel- 7 is having maximum first fruiting node (14.57). The maximum length of first fruiting node was recorded in Sel-3 $(47.03 \mathrm{~cm})$. Very optimum dose of NPK reduce the days taken to flowering up to a certain limit and vice versa. Similar results were coated by Naeem et al., (2002) for chilli.

The maximum number of pods per plant was recorded in KS-210 i.e. 38.60. KS-149 showed maximum length of pod $(10.09 \mathrm{~cm})$ and width of pod $(1.49 \mathrm{~cm})$. The performance of pea with respect to germination and nodulation was influenced by the temperature, 
rainfall, humidity etc. The deficiency of major nutrients stunted the plant growth, resulting the maximum days taken to flowering. The cultivar KS-156 had maximum number of seeds (9.53). Pod yield per plant and pod yield $\mathrm{q} / \mathrm{ha}$ is highest in PB 89 i.e. $182.99 \mathrm{~g}$ and $73.20 \mathrm{q} / \mathrm{ha}$ respectively. The plants treated with different combinations of NPK and NADEP compost results in to higher length of pods. Similar results were reported by Parsad et al., (2005).

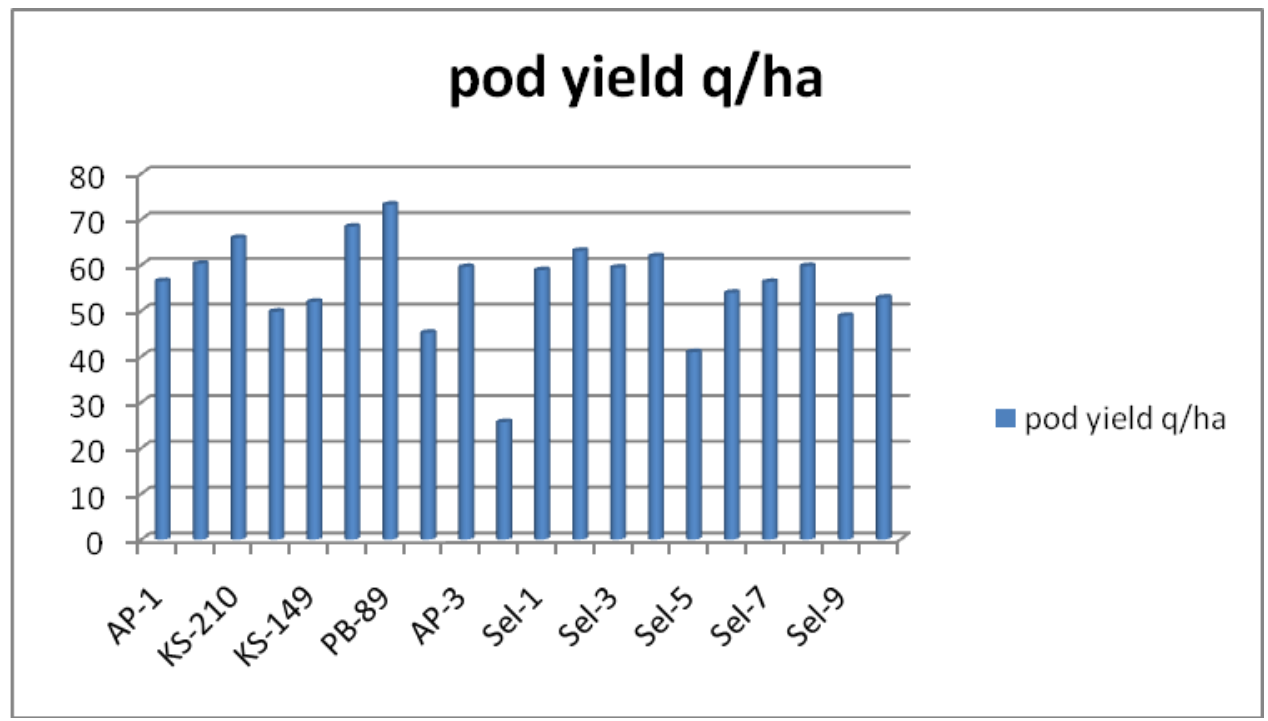

Table.1 ANOVA

\begin{tabular}{|c|c|c|c|c|c|c|c|c|c|c|c|}
\hline $\begin{array}{l}\text { Source of } \\
\text { Variation }\end{array}$ & DF & $\begin{array}{l}\text { Days to } \\
50 \% \\
\text { flowering }\end{array}$ & $\begin{array}{l}\text { Plant } \\
\text { height } \\
(\mathrm{cm})\end{array}$ & $\begin{array}{c}\text { Number } \\
\text { of first } \\
\text { fruiting } \\
\text { node }\end{array}$ & $\begin{array}{l}\text { Length } \\
\text { of first } \\
\text { fruiting } \\
\text { node } \\
(\mathrm{cm})\end{array}$ & $\begin{array}{l}\text { Number } \\
\text { of pods } \\
\text { per plant }\end{array}$ & $\begin{array}{l}\text { Length } \\
\text { of pod } \\
(\mathrm{cm})\end{array}$ & $\begin{array}{l}\text { Width } \\
\text { of pod } \\
(\mathrm{cm})\end{array}$ & $\begin{array}{l}\text { seeds } \\
\text { per } \\
\text { pod }\end{array}$ & $\begin{array}{c}\text { pod } \\
\text { yield } \\
\text { q/ha }\end{array}$ & $\begin{array}{c}\text { pod } \\
\text { yield } \\
\text { per } \\
\text { plant }(g)\end{array}$ \\
\hline $\begin{array}{l}\text { Replicatio } \\
\mathrm{n}\end{array}$ & 2 & 4.55 & 0.66 & 0.05 & 0.68 & 0.52 & 0.20 & 0.00 & 0.01 & 0.05 & 0.01 \\
\hline Treatment & 19 & $195.60 * *$ & $\begin{array}{r}944.88 \\
* *\end{array}$ & $5.37 * *$ & $\begin{array}{r}186.58^{*} \\
*\end{array}$ & $\begin{array}{r}137.56 \\
* *\end{array}$ & $1.88 * *$ & $0.01^{*}$ & $\begin{array}{r}3.50 \\
* * \\
\end{array}$ & $\begin{array}{r}2050.9 \\
3 * *\end{array}$ & $\begin{array}{r}328.16 \\
* *\end{array}$ \\
\hline Error & 38 & 1.32 & 0.64 & 0.42 & 0.24 & 0.20 & 0.18 & 0.00 & 0.24 & 2.98 & 0.48 \\
\hline
\end{tabular}

Table.2 Average of intra and inter cluster distance

\begin{tabular}{|c|c|c|c|c|}
\hline Clusters & I & II & III & IV \\
\hline I & $\mathbf{1 . 9 4 3}$ & 5.917 & 6.627 & 6.304 \\
\hline II & & $\mathbf{1 . 9 8 3}$ & 2.82 & 3.86 \\
\hline III & & & $\mathbf{1 . 9 7 6}$ & 2.763 \\
\hline IV & & & & $\mathbf{1 . 6 2 1}$ \\
\hline
\end{tabular}


Table.3 Mean performance of 20 genotypes of pea for 10 characters

\begin{tabular}{|c|c|c|c|c|c|c|c|c|c|c|c|}
\hline S.no. & $\begin{array}{l}\text { Geno- } \\
\text { types }\end{array}$ & $\begin{array}{c}\text { Days to } \\
\mathbf{5 0 \%} \\
\text { flowering }\end{array}$ & $\begin{array}{c}\text { Plant } \\
\text { height } \\
\text { (cm) }\end{array}$ & $\begin{array}{c}\text { Number of } \\
\text { first fruiting } \\
\text { node }\end{array}$ & $\begin{array}{c}\text { Length of first } \\
\text { fruiting } \\
\text { node }(\mathrm{cm})\end{array}$ & $\begin{array}{c}\text { Number of } \\
\text { pods per } \\
\text { plant }\end{array}$ & $\begin{array}{c}\text { Length } \\
\text { of pod } \\
(\mathrm{cm})\end{array}$ & $\begin{array}{l}\text { Width of } \\
\text { pod }(\mathrm{cm})\end{array}$ & $\begin{array}{l}\text { seeds } \\
\text { / pod }\end{array}$ & $\begin{array}{l}\text { pod yield } \\
\text { /plant(g) }\end{array}$ & $\begin{array}{c}\text { pod yield } \\
\text { q/ha }\end{array}$ \\
\hline 1 & AP-1 & 52.67 & 82.45 & 11.67 & 37.25 & 34.87 & 9.35 & 1.26 & 8.60 & 141.15 & 56.46 \\
\hline 2 & KS-156 & 46.33 & 45.36 & 12.87 & 31.42 & 32.40 & 9.35 & 1.32 & 9.53 & 150.66 & 60.27 \\
\hline 3 & KS-210 & 55.33 & 55.37 & 14.07 & 46.07 & 38.60 & 8.63 & 1.25 & 7.73 & 164.81 & 65.93 \\
\hline 4 & AP-4 & 50.33 & 56.00 & 13.67 & 37.26 & 31.67 & 9.41 & 1.23 & 8.73 & 124.51 & 49.80 \\
\hline 5 & KS-149 & 55.33 & 55.51 & 13.73 & 36.77 & 28.73 & 10.09 & 1.49 & 9.20 & 129.91 & 51.96 \\
\hline 6 & KS-205 & 54.67 & 56.31 & 13.40 & 41.12 & 36.13 & 8.72 & 1.33 & 7.33 & 170.98 & 68.39 \\
\hline 7 & \begin{tabular}{|l|} 
PB-89 \\
\end{tabular} & 52.67 & 54.39 & 11.53 & 45.55 & 37.40 & 7.17 & 1.35 & 8.33 & 182.99 & 73.20 \\
\hline 8 & AP-2 & 62.33 & 64.73 & 12.53 & 46.75 & 26.27 & 8.44 & 1.34 & 5.80 & 112.96 & 45.18 \\
\hline 9 & AP-3 & 35.67 & 37.34 & 11.53 & 28.49 & 32.80 & 9.33 & 1.31 & 9.27 & 148.93 & 59.57 \\
\hline 10 & E-6 & 32.67 & 32.27 & 8.87 & 17.23 & 11.60 & 7.37 & 1.25 & 6.73 & 64.20 & 25.68 \\
\hline 11 & Sel-1 & 48.67 & 48.19 & 13.07 & 31.71 & 32.87 & 9.21 & 1.32 & 9.20 & 147.21 & 58.89 \\
\hline 12 & Sel-2 & 55.33 & 88.18 & 12.60 & 46.25 & 38.20 & 8.25 & 1.29 & 7.20 & 157.79 & 63.12 \\
\hline 13 & Sel-3 & 53.67 & 96.37 & 12.93 & 47.03 & 35.07 & 9.42 & 1.32 & 6.73 & 148.59 & 59.44 \\
\hline 14 & Sel-4 & 58.33 & 75.69 & 13.67 & 35.33 & 36.40 & 7.58 & 1.23 & 8.27 & 154.79 & 61.92 \\
\hline 15 & Sel-5 & 38.67 & 53.98 & 10.60 & 23.99 & 17.73 & 9.16 & 1.29 & 6.80 & 102.40 & 40.96 \\
\hline 16 & Sel-6 & 34.67 & 76.13 & 13.87 & 38.52 & 31.27 & 8.55 & 1.24 & 8.80 & 134.85 & 53.94 \\
\hline 17 & Sel-7 & 51.67 & 68.30 & 14.53 & 38.05 & 35.27 & 8.06 & 1.25 & 7.40 & 140.73 & 56.29 \\
\hline 18 & Sel-8 & 49.33 & 78.44 & 12.33 & 39.27 & 36.73 & 8.70 & 1.26 & 8.73 & 149.40 & 59.76 \\
\hline 19 & Sel-9 & 50.33 & 90.41 & 13.53 & 42.01 & 29.27 & 9.04 & 1.30 & 6.73 & 122.18 & 48.87 \\
\hline \multirow[t]{7}{*}{20} & Sel-10 & 48.33 & 69.13 & 12.67 & 35.87 & 32.87 & 7.69 & 1.23 & 8.67 & 132.13 & 52.85 \\
\hline & Mean & 49.35 & 64.23 & 12.68 & 37.30 & 31.81 & 8.68 & 1.29 & 7.99 & 139.06 & 55.62 \\
\hline & Range & 32.67 & 32.27 & 8.87 & 17.23 & 11.60 & 7.17 & 1.23 & 5.80 & 64.20 & 25.68 \\
\hline & & 62.33 & 96.37 & 14.53 & 47.03 & 38.60 & 10.09 & 1.49 & 9.53 & 182.99 & 73.20 \\
\hline & SE & 0.94 & 0.65 & 0.53 & 0.40 & 0.36 & 0.35 & 0.03 & 0.40 & 1.41 & 0.56 \\
\hline & CD at $5 \%$ & 1.99 & 1.38 & 1.12 & 0.85 & 0.77 & 0.73 & 0.07 & 0.85 & 2.98 & 1.19 \\
\hline & Mean & 49.35 & 64.23 & 12.68 & 37.30 & 31.81 & 8.68 & 1.29 & 7.99 & 139.06 & 55.62 \\
\hline
\end{tabular}


Table.4 Cluster mean of 10 characters of pea

\begin{tabular}{|c|l|c|c|c|c|c|c|c|c|c|c|}
\hline $\begin{array}{c}\text { Cluster } \\
\text { S }\end{array}$ & $\begin{array}{c}\text { Days to } \\
\text { 50\% } \\
\text { flowerin } \\
\mathbf{g}\end{array}$ & $\begin{array}{c}\text { Plant } \\
\text { height } \\
\text { (cm) }\end{array}$ & $\begin{array}{c}\text { Numbe } \\
\text { r of } \\
\text { first } \\
\text { fruiting } \\
\text { node }\end{array}$ & $\begin{array}{c}\text { Lengt } \\
\text { h of } \\
\text { first } \\
\text { fruitin } \\
\text { g node } \\
\text { (cm) }\end{array}$ & $\begin{array}{c}\text { Numb } \\
\text { er of } \\
\text { pods } \\
\text { per } \\
\text { plant }\end{array}$ & $\begin{array}{c}\text { Lengt } \\
\text { h of } \\
\text { pod } \\
\text { (cm) }\end{array}$ & $\begin{array}{c}\text { Width } \\
\text { of pod } \\
\text { (cm) }\end{array}$ & $\begin{array}{c}\text { Numb } \\
\text { er of } \\
\text { seeds } \\
\text { per } \\
\text { pod }\end{array}$ & $\begin{array}{c}\text { pod } \\
\text { vield } \\
\text { per } \\
\text { plant( } \\
\text { g) }\end{array}$ & $\begin{array}{c}\text { pod } \\
\text { yield } \\
\text { q/ha) }\end{array}$ \\
\hline I & Mean & 35.67 & 43.13 & 9.73 & 20.61 & 14.67 & 8.27 & 1.27 & 6.77 & 83.30 & 33.32 \\
\hline II & Mean & 47.27 & 48.48 & 12.97 & 33.13 & 31.69 & 9.48 & 1.34 & 9.19 & 140.24 & 56.10 \\
\hline III & Mean & 51.30 & 70.44 & 13.03 & 40.33 & 35.77 & 8.27 & 1.27 & 8.11 & 152.96 & 61.19 \\
\hline IV & Mean & 55.44 & 83.84 & 13.00 & 45.26 & 30.20 & 8.97 & 1.32 & 6.42 & 127.91 & 51.16 \\
\hline
\end{tabular}

Table.5 Clustering pattern of 20 genotypes of pea on the basis of genetic divergence

\begin{tabular}{|c|r|l|}
\hline Clusters & \multicolumn{1}{|c|}{$\begin{array}{c}\text { No of } \\
\text { genotypes }\end{array}$} & \multicolumn{1}{c|}{ Genotype name } \\
\hline I & 2 & E-6, Selection-5 \\
\hline II & 5 & KS-156,AP-4,KS-149, AP-3,Selection-1 \\
\hline III & 10 & $\begin{array}{l}\text { AP-1, KS-210, KS-205,PB-89,Selection-2, Selection-4, Selection-6, } \\
\text { Selection-7,Seletion-8, Selection-10 }\end{array}$ \\
\hline IV & 3 & AP-2, Selection-3, Selection-9 \\
\hline
\end{tabular}

On the basis of Mahalanobis $\mathrm{D}^{2}$ analysis, total 20 genotypes were studied and grouped into four clusters. The distribution patterns of pea genotypes into four clusters are presented in Table 5. The maximum number of genotypes 10 was found in cluster III with comprising AP-1, KS-210, KS-205, PB -89, SELECTION2, SELECTION-4, SELECTION-6, SELECTION-7, SELECTION-8, SELECTION10. The second highest number of genotypes (5) were claimed under cluster II namely KS156, AP-4, KS-149, AP-3, SELCTION-1. The cluster IV comprising was found (3) genotypes namely AP-2, SELECTION-3, SELECTION-9, while cluster I containing (2) genotypes namely E-6, SELECTION-5.

The average intra and inter cluster $\mathrm{D}^{2}$ values are presented in Table 2. The maximum inter cluster $\mathrm{D}^{2}$ value (6.627) was recorded between cluster III and I and the minimum inter cluster $\mathrm{D}^{2}$ value (2.763) was recorded in cluster IV and III. The maximum intra cluster distance were found in cluster III (1.976) followed by cluster I (1.943), cluster II (1.983) and cluster IV (1.621). The maximum inter cluster $\mathrm{D}^{2}$ values indicated that genotypes of cluster III and I were not closely related, whereas the genotypes of cluster IV and III were found closely related due to minimum inter cluster $\mathrm{D}^{2}$ values. It is apparent therefore, the genotypes of cluster do not differ significantly with regards to their relative genetic distance as indicated from the low variation of $\mathrm{D}^{2}$ values.

The success of breeding programmes depends upon the genetic diversity present among the parents. Divergence study suggested that crosses among genotypes like KS-156, AP-4, KS-149, AP-1, KS-210, KS-205 for getting desired segregates from breeding point of view. 


\section{References}

Choudhary, B. 1990. Vegetables, National Book Trust, India, A-5 Green Park, New Delhi-16

Ghafoor, A., Ahmad, Z. and Anwar, R. (2005). Genetic diversity in Pisum sativum and a strategy for indigenous biodiversity conservation. Pakistan Journal of Botany, 37: 71-77

Naeem, N.M. Irfan, J. Khan, G. Nabi N. Muhammad and N. Badshah, 2002. Influence of various levels of nitrogen and phosphorus on growth and yield of chilli (Capsicum annum L.) Asian J. Pl Sci. 1: 599-601.

Nisar, M., Ghafoor, A., Ahmad, H., Khan, M. R., Qureshi, A.S., Ali, H. and Islam, M.(2008). Evaluation of genetic diversity of pea germplasm through phenotypic trait analysis. Pak. J. Bot., 40(5): 2081-2086.

Prasad, Kader, Kumar Sanjay, Pyare, J.P.S. (2005). Effect of FYM and biofertilizers in conjunction with inorganic fertilizers on growth, yield and profit of chick pea (Cicer arietinum L.). Plant achieves 5(2): 609-612.

Rao, C.R. (1952). Advance Statistical Methods in Biometrical Research (Ist Edn). John Willey and Sons, New York. Pp. 390. (1952).

Sajjad, M., Khan, S. and Khan, A. S. (2011). Exploitation of germplasm for grain yield improvement in spring wheat (Triticum aestivum). International Journal of Agriculture and Biology, 13: 695-700.

\section{How to cite this article:}

Archi Gupta, M.K. Singh, Mukesh Kumar, S.K. Singh, Hariom Katiyar and Vipin Kumar. 2017. Study of Genetic Divergence in Pea (Pisum sativum L.) based on Agro-Morphic Traits. Int.J.Curr.Microbiol.App.Sci. 6(11): 3816-3821. doi: https://doi.org/10.20546/ijcmas.2017.611.448 